\title{
The inhibitory action of Bauhinia purpurea extracts on the corrosion of carbon steel in sulfuric acid medium
}

\author{
Iuri Bezerra de Barros ${ }^{a}$, Marco André Abud Kappel ${ }^{a}$, Priscila Moraes dos Santos ${ }^{b}$, \\ Valdir Florêncio da Veiga Junior ${ }^{b}, E^{2}$ liane D’Eliac ${ }^{c}$, Ivan Napoleão Bastos ${ }^{a *}$ \\ ${ }^{a}$ Instituto Politécnico, Universidade do Estado do Rio de Janeiro - UERJ, \\ Rua Bonfim, 25, CEP 28625-570, Nova Friburgo, RJ, Brazil \\ ${ }^{b}$ Departamento de Química, Universidade Federal do Amazonas - UFAM, \\ Av. Rodrigo Octávio, 6200, CEP 69077-000, Manaus, AM, Brazil \\ ${ }^{c}$ Departamento de Química Inorgânica, Universidade Federal do Rio de Janeiro - UFRJ, \\ Av. Athos da Silveira Ramos, 149, CEP 21941-909, Rio de Janeiro, RJ, Brazil
}

Received: August 24, 2015; Revised: November 10, 2015; Accepted: November 26, 2015

The inhibitory effect of Bauhinia purpurea (Fabaceae) extract was studied in the corrosion of carbon steel in $1.0 \mathrm{~mol} \cdot \mathrm{L}^{-1}$ sulfuric acid solution. This plant was collected from the Brazilian rainforest. The carbon steel protection was observed by varying the extract concentration from 50 to $500 \mathrm{mg} \cdot \mathrm{L}^{-1}$. Polarization curves revealed that this extract acted as an adsorption inhibitor decreasing both anodic and cathodic density currents. Weight loss measurements showed that the extract remains stable for at least 72 hours. The adsorption process of this extract obeyed the Langmuir adsorption isotherm. Lastly, Arrhenius plot suggested the physical adsorption of the extract.

Keywords: Fabaceae; Flavonoids; Polarization; Weight loss

\section{Introduction}

Several industrial technologies use hydrochloric and sulfuric acids in their engineering processes. In this context, the search for corrosion inhibitors in acidic media to protect metallic surfaces has established the natural products as a rich and promising source. The protective efficiency appears to increase with the presence of oxygen, nitrogen, sulphur and $\pi$ electrons in the organic compounds ${ }^{1-4}$. Apparently, the inhibition efficiency is linked to the polar functions that act as the reaction center for the adsorption process ${ }^{5}$.

The environmental toxicity of organic corrosion inhibitors has prompted the search for green corrosion inhibitors as they are biodegradable and do not contain heavy metals or other toxic compounds. Plant products are inexpensive, readily available and renewable ${ }^{4}$, as well as environmentally friendly and ecologically acceptable.

Species of the genus Bauhinia (Fabaceae) have been used to treat several diseases in traditional medicine. For instance, Bauhinia purpurea has shown antidiabetic, analgesic, anti-inflammatory, antipyretic, antimalarial, antifungal, cytotoxic and thyroid hormone-stimulating activities as well as free radical scavenging ${ }^{6-14}$.

Phytochemical studies with Bauhinia purpurea had related the presence of several molecules which could be potential corrosion inhibitors, such as flavonoids (rutin ${ }^{7}$, isoquercetrin ${ }^{7}$, 5,6-dihydroxy-7-methoxyflavone 6-O- $\beta$-D-xylopyranoside ${ }^{15}$, kaempferol ${ }^{16}$, quercetin ${ }^{16}$, isohammetin ${ }^{16}$, strobopinin ${ }^{6}$, demothoxymatteucinol ${ }^{6}$, bauhinoxepin $\mathrm{C}^{-\mathrm{J}^{6}}$ and bauhinistatins $1-4^{1}$ )

*e-mail: inbastos@iprj.uerj.br in addition to phytosterols and fatty acids ${ }^{17}$. The phenolic compound extraction is enhanced using methanol solvent ${ }^{18,19}$.

The aim of this study was to evaluate the inhibitory effects of methanolic Bauhinia purpurea leaf extract as corrosion inhibitor for carbon steel in a $1.0 \mathrm{~mol} \cdot \mathrm{L}^{-1}$ sulfuric acid solution. Open-circuit potential monitoring, potentiodynamic polarization curves, electrochemical impedance spectroscopy, weight loss measurements and also surface morphology analysis were employed to reach this objective.

\section{Experimental}

\subsection{Plant extraction and characterization}

Bauhinia purpurea L. leaves were collected from São Gabriel da Cachoeira-AM, Brazil. The voucher (number 7657) specimen was deposited at the herbarium of Universidade Federal do Amazonas, Manaus - AM, Brazil. The leaves were dried in the dark for seven days at room temperature, subsequently cleaned and powdered. Macerated extracts were obtained by mixing $700.0 \mathrm{~g}$ of dry leaf powder with methanol at room temperature. The extract was filtered and evaporated under vacuum to dry. The methanolic extract was stored at $4.0^{\circ} \mathrm{C}$ until the tests.

\subsection{Mass spectroscopy - MS-ESI}

The mass spectra of the methanolic leaf extract of Bauhinia purpurea were acquired in continuous monitoring mode (Thermo LCQ Fleet Tune Application) using an ion-trap mass spectrometer (Thermo LCQ Fleet) equipped 
with an ESI source in negative mode. The stock sample was prepared with methanol (HPLC grade) in a concentration of $1000 \mathrm{mg} \cdot \mathrm{L}^{-1}$, then diluted to $10 \mathrm{mg} \cdot \mathrm{L}^{-1}$ and analyzed by direct infusion via the instrument syringe pump $\left(8 \mu \mathrm{L} \cdot \mathrm{min}^{-1}\right)$. The full spectrum was obtained in the range of $100-1000 \mathrm{~m} / \mathrm{z}$. Rutin and isoquercetrin certified samples were used to confirm the presence of these flavonoids in the extract.

\subsection{Electrochemical procedure}

The electrochemical measurements were conducted in a thermostated three-electrode cell. A saturated calomel electrode (SCE) was used as reference electrode and the counter electrode was a large area platinum wire. The electrolyte was $1.0 \mathrm{~mol} \cdot \mathrm{L}^{-1} \mathrm{H}_{2} \mathrm{SO}_{4}$ prepared from concentrated reagent analytical grade (Vetec Fine Chemicals Ltda, Brazil). All experiments were performed in $200 \mathrm{~mL}$ of electrolytes under non-stirred and naturally aerated conditions. The temperature was controlled at $25.0 \pm 0.2{ }^{\circ} \mathrm{C}$.

Carbon steel UNS G10200, hereafter named C-steel, was used as a working electrode. The electrodes were prepared by embedding the steel rods in epoxy resin and exposing a surface area of $0.33 \mathrm{~cm}^{2}$ to the electrolyte. Prior to each measurement, the sample surfaces were abraded with 600 grade emery paper under water flow, washed with double-distilled water, degreased with ethanol and dried in warm air. In all experiments, the C-steel electrode was allowed to reach its stable open-circuit potential (OCP), which occurred after $1.0 \mathrm{~h}$. After this period, the electrochemical impedance spectroscopy (EIS) measurement was performed over a frequency range of $20 \mathrm{kHz}$ to $10 \mathrm{mHz}$ at the stable open-circuit potential with an $\mathrm{AC}$ wave of $8 \mathrm{mV}$ and 10 points per decade. Subsequently, the polarization curves were performed from the cathodic to the anodic direction from $-300 \mathrm{mV}$ below the open-circuit potential up to $300 \mathrm{mV}$ above it, with a scan rate of $1.0 \mathrm{mV} \cdot \mathrm{s}^{-1}$. All electrochemical experiments were performed in triplicate using a Gamry Reference 600 potentiostat.

The inhibition efficiency $(\eta \%)$ was calculated from potentiodynamic polarization curves and electrochemical impedance diagrams, as shown in Equations (1) and (2), respectively:

$$
\eta \%=\frac{j_{\text {corr }, 0}-j_{\text {corr }}}{j_{\text {corr }, 0}} \times 100
$$

where $j_{\text {corr }, 0}$ is the corrosion current density in the absence of inhibitor, and $j_{\text {corr }}$ is the corrosion current density in the presence of inhibitor, obtained from Tafel plots.

Furthermore, the charge-resistance obtained from the EIS and fitted employing Differential Evolution technique with the use of the equivalent electric circuit of Figure 1 was used to evaluate the inhibition effect, as follows;

$\eta \%=\frac{R_{c t}-R_{c t, 0}}{R_{c t}} \times 100$

where $R_{c t, 0}$ is the charge-transfer resistance in the absence of inhibitor, and $R_{c t}$ is the charge-transfer resistance in the presence of inhibitor. The blank condition was $1.0 \mathrm{~mol} \cdot \mathrm{L}^{-1} \mathrm{H}_{2} \mathrm{SO}_{4}$ without inhibitor.

As a stochastic direct search technique, Differential Evolution is able to handle non-differentiable, nonlinear and

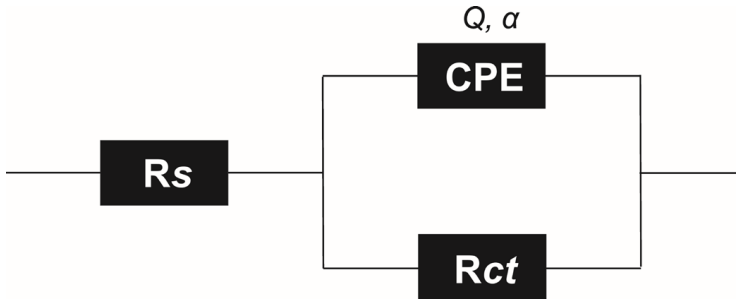

Figure 1: Equivalent circuit used to fit the EIS data of C-steel in $1.0 \mathrm{~mol} \cdot \mathrm{L}^{-1} \mathrm{H}_{2} \mathrm{SO}_{4}$ without and with different concentrations of Bauhinia purpurea extract.

multi-modal objective functions. Moreover, the method has good convergence properties, i.e., good convergence to the global minimum in independent tests ${ }^{20}$.

\subsection{Weight loss experiment}

C-steel coupons (25.0 $\mathrm{mm} \times 20.0 \mathrm{~mm} \times 1.0 \mathrm{~mm})$ of the same alloy that was used in the electrochemical measurements were abraded with 100 grade emery paper under water flow, washed with deionized water, degreased with ethanol, and dried in hot air. Triplicate specimens were immersed in the acid test solution for $24 \mathrm{~h}$ at $25{ }^{\circ} \mathrm{C}$ in the absence and presence $\left(50,125,250\right.$ and $\left.500 \mathrm{mg} \cdot \mathrm{L}^{-1}\right)$ of methanolic Bauhinia purpurea leaf extract. The specimens were cleaned, washed with deionized water and ethanol, dried in warm air. Weight loss was determined by gravimetric tests using an analytical balance, Ohaus AS200, with precision of $0.1 \mathrm{mg}$. The inhibition efficiency ( $\eta \%$ ) was determined using Eq. (3):

$\eta \%=\frac{W_{0}-W}{W_{0}} x 100$

where $W_{0}$ and $W$ are the weight 1 oss in the absence and presence of the extract, respectively.

The time and temperature effects on the corrosion rate of steel coupons in $1.0 \mathrm{~mol} \cdot \mathrm{L}^{-1} \mathrm{H}_{2} \mathrm{SO}_{4}$ were examined. These experiments were performed in the absence and presence of $250 \mathrm{mg} \cdot \mathrm{L}^{-1}$ of methanolic Bauhinia purpurea (Fabaceae) leaf extract for 24,48 and $72 \mathrm{~h}$ at $25^{\circ} \mathrm{C}$; and during an immersion period of $2.0 \mathrm{~h}$ at $25,35,45$ and $55^{\circ} \mathrm{C}$.

\subsection{Surface analysis}

The samples used in the surface morphology examination were immersed in $1.0 \mathrm{~mol} \mathrm{~L}^{-1} \mathrm{H}_{2} \mathrm{SO}_{4}$ in the absence and presence of $250 \mathrm{mg} \cdot \mathrm{L}^{-1}$ of methanolic Bauhinia purpurea leaf extract at $25^{\circ} \mathrm{C}$ for $2.0 \mathrm{~h}$. The images were taken using Hitachi TM 3000 scanning electron microscope with an accelerating voltage of $15 \mathrm{kV}$.

\section{Results and discussion}

\subsection{Potentiodynamic polarization curves}

The stable open-circuit potential (OCP) was measured after one hour exposure (Figure 2). Figure 3 presents the potentiodynamic polarization curves of $\mathrm{C}$-steel in $1.0 \mathrm{~mol} \cdot \mathrm{L}^{-1} \mathrm{H}_{2} \mathrm{SO}_{4}$ with and without methanolic Bauhinia purpurea extract at $25^{\circ} \mathrm{C}$. The other electrochemical parameters, i.e., the corrosion potential $\left(E_{\text {corr }}\right)$, the corrosion current density $\left(J_{\text {corr }}\right)$ and the anodic $\left(\beta_{a}\right)$ and cathodic $\left(\beta_{c}\right)$ 
constants, shown in Table 1, were obtained by fitting the Tafel plots.

It can be observed from the potentiodynamic polarization curves that the presence of Bauhinia purpurea extract caused a decrease in both the anodic and cathodic current densities. These results could be explained by the adsorption of organic compounds present in the extracts at the active sites of the electrode surface, which also led to the retardation of metallic dissolution and hydrogen evolution, and consequently slowing the corrosive process.

It can be observed from Table 1 that the corrosion current density $\left(j_{\text {corr }}\right)$ decreases by increasing the concentration of the

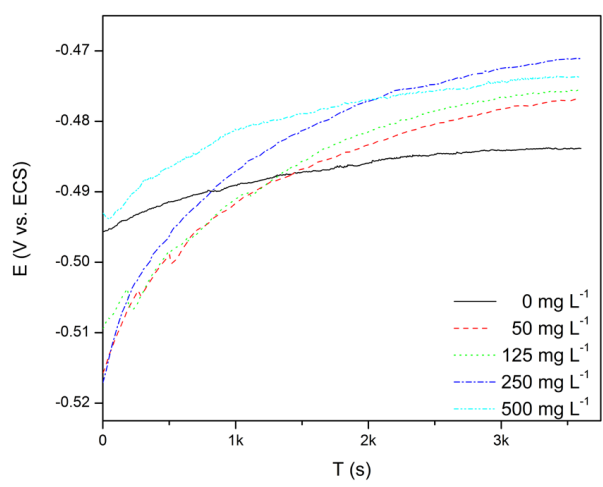

Figure 2: Open circuit potential (OCP) of C-steel in $1.0 \mathrm{~mol} \cdot \mathrm{L}^{-1}$ $\mathrm{H}_{2} \mathrm{SO}_{4}$ with and without methanolic Bauhinia purpurea extract at the following concentrations: $50,125,250$ and $500 \mathrm{mg} \cdot \mathrm{L}^{-1}$ at $25^{\circ} \mathrm{C}$.

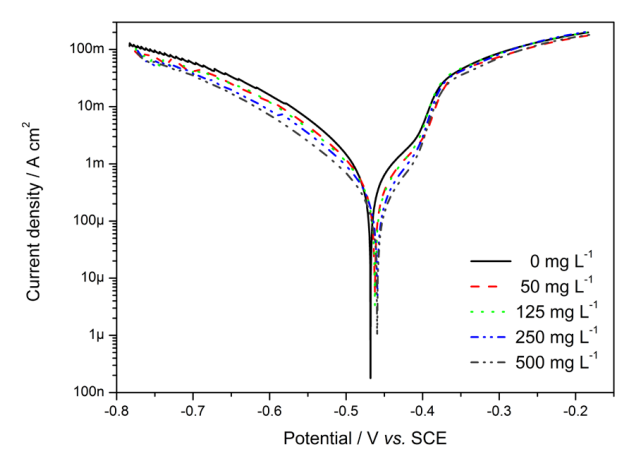

Figure 3: Polarization curve of C-steel in $1.0 \mathrm{~mol} \cdot \mathrm{L}^{-1} \mathrm{H}_{2} \mathrm{SO}_{4}$ with and without methanolic Bauhinia purpurea extract at the following concentrations: $50,125,250$ and $500 \mathrm{mg} \cdot \mathrm{L}^{-1}$ at $25^{\circ} \mathrm{C}$. inhibitor. Additionally, in the presence of the extract, both OCP (Open Circuit Potential) and $E_{\text {corr }}$ slightly shifted to more anodic potentials compared to the blank (maxima shifts of 16 and $10 \mathrm{mV}$ in the presence of $250 \mathrm{mg} \cdot \mathrm{L}^{-1}$, respectively), demonstrating that this extract acts as a mixed-type inhibitor. The cathodic Tafel slopes $\left(\beta_{c}\right)$ did not change significantly with the addition of the extract (Table 1), indicating that the adsorbed inhibitor molecules did not affect the hydrogen evolution reaction, i.e., hydrogen evolution diminished exclusively by the surface blocking effect. Regarding the anodic region of the potentiodynamic polarization curves, a decrease in the anodic Tafel slopes $\left(\beta_{a}\right)$ can be observed with the addition of inhibitor. This result reveals that the inhibitor adsorbed to the carbon steel could modify the metal dissolution reaction. The inhibition efficiency calculated from the $j_{\text {corr }}$ values obtained in the absence and presence of Bauhinia purpurea extract varied from 22 to $67 \%$ over a concentration range of $50-500 \mathrm{mg} \cdot \mathrm{L}^{-1}$.

\subsection{Electrochemical impedance spectroscopy (EIS)}

Figure 4 illustrates the Nyquist plots of C-steel in a $1.0 \mathrm{~mol} \cdot \mathrm{L}^{-1} \mathrm{H}_{2} \mathrm{SO}_{4}$ with and without methanolic Bauhinia purpurea extract at $25^{\circ} \mathrm{C}$. It can be observed in all curves a large capacitive loop at high frequencies followed by a small inductive loop at low frequencies. The high frequency capacitive loop is usually related to the charge transfer of the corrosion process and double layer behavior. However, the low frequency inductive loop may be attributed to the relaxation process obtained from adsorption species like $\mathrm{FeSO}_{4}$, inhibitor species or $H_{a d s}^{+}$on the electrode surface. It might be

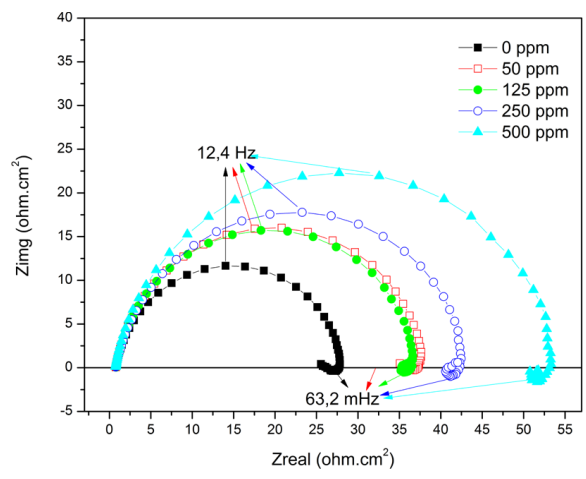

Figure 4: Nyquist plots obtained at the OCP for C-steel in $1.0 \mathrm{~mol} \cdot \mathrm{L}^{-1} \mathrm{H}_{2} \mathrm{SO}_{4}$ with and without of methanolic Bauhinia purpurea extract at the following concentrations: $50,125,250$ and $500 \mathrm{mg} \cdot \mathrm{L}^{-1}$ at $25^{\circ} \mathrm{C}$.

Table 1: Kinetic parameters obtained from Tafel plots for C-steel in $1.0 \mathrm{~mol} \mathrm{~L}^{-1} \mathrm{H}_{2} \mathrm{SO}_{4}$ with and without methanolic Bauhinia purpurea extract at the following concentrations: $50,125,250$ and $500 \mathrm{mg} \cdot \mathrm{L}^{-1}$ at $25^{\circ} \mathrm{C}$.

\begin{tabular}{ccccccc}
\hline $\begin{array}{c}\text { Inhibitor } \\
\left(\mathbf{m g} \cdot \mathbf{L}^{-1}\right)\end{array}$ & $\mathbf{O C P}(\mathbf{m V} / \mathbf{S C E})$ & $\boldsymbol{E}_{\text {corr }}(\mathbf{m v} / \mathbf{S C E})$ & $\boldsymbol{j}_{\text {corr }}\left(\boldsymbol{\mu} \mathbf{A} \cdot \mathbf{c m}^{-2}\right)$ & $\boldsymbol{\beta}_{\boldsymbol{a}}(\boldsymbol{m} \boldsymbol{V} / \mathbf{d e c})$ & $\boldsymbol{\beta}_{\boldsymbol{c}}(\boldsymbol{m} \boldsymbol{V} / \mathbf{d e c})$ & $\boldsymbol{\eta}(\mathbf{\%})$ \\
\hline 0 & -488 & -469 & 763 & 109 & 86 & - \\
50 & -476 & -463 & 597 & 97 & 92 & 22 \\
125 & -478 & -465 & 406 & 77 & 82 & 47 \\
250 & -472 & -459 & 319 & 74 & 81 & 58 \\
500 & -476 & -463 & 251 & 76 & 84 & 67 \\
\hline
\end{tabular}


also attributed to the re-dissolution of the passivated surface at low frequencies ${ }^{21}$.

The EIS spectra were analyzed using the equivalent circuit (Figure 1), where $R_{s}$ represents the ohmic resistance of the solution and $R_{c t}$ represents the charge transfer resistance whose value is a measurement of electron transfer across the surface and is inversely proportional to corrosion rate. It is worth mentioning that the double layer capacitance value is affected by heterogeneity of the surface. Therefore, the constant phase element (CPE) is introduced in the circuit instead a pure double layer capacitor to give more accurate $\mathrm{fit}^{22}$. The impedance of the CPE is expressed by the following expression:

$Z_{C P E}=\frac{1}{Q(i w)^{\alpha}}$

where $\mathrm{Q}$ is the magnitude of the CPE, with $-1 \leq \alpha \leq 1$. The capacitive loops have depressed semi-circular appearance, $0.5 \leq \alpha \leq 1$, which is often referred to as frequency dispersion as a result of the nonhomogeneity or the roughness of the solid surface ${ }^{23-25}$. The factor $i$ is the imaginary number $\left(i^{2}=-1\right)$. Normally, the exponent $\alpha$ represents the degree of non-ideality in capacitive behavior. The exponent value makes it possible to differentiate the behavior of a CPE $(\alpha<1)$ from that of an ideal capacitor $(\alpha=1)$.

The impedance parameters, including $R_{c}, Q$ and $\alpha$ obtained from fitting the recorded EIS data using the equivalent circuit of Figure 1, are listed in Table 2 with the percentage of inhibition efficiency $(\eta \%)$. Based on Table 2 , it is clear that the $R$ values increased with increasing inhibitor concentration. These results may be attributable to the adsorption of some components of the extract onto the metal/solution interface. Indeed, this hypothesis is corroborated by the anodic and cathodic polarization curves and the corrosion potential results. The inhibition efficiency values $(\eta \%)$ were calculated from $R_{c t}$ data in the absence and presence of the extract yielding $49 \%$ for the highest concentration.

The Differential Evolution optimization of the equivalent circuit parameters was also used to generate a confidence region, which shows an approximately elliptical shape, indicating a degree of linearity of these factors ${ }^{26}$. Figure 5 shows that the $99 \%$ confidence region of $\mathrm{Q}$ and $\alpha$ is approximately elliptical and sloping, which means there is a linear dependence between these parameters.

\subsection{Weight loss}

The results of weight loss measurements for the corrosion of C-steel in $1.0 \mathrm{~mol} \cdot \mathrm{L}^{-1} \mathrm{H}_{2} \mathrm{SO}_{4}$ with and without methanolic Bauhinia purpurea extract in different concentrations $\left(50,125,250\right.$ and $\left.500 \mathrm{mg} \cdot \mathrm{L}^{-1}\right)$ for $24 \mathrm{~h}$ at $25.0{ }^{\circ} \mathrm{C}$ are provided in Table 3. Again the $\eta \%$ increases with the extract concentration, varying from 58 to $80 \%$, as it was observed in the electrochemical studies. This efficiency is similar to the results of Patel et al. ${ }^{27}$.

The results of the weight loss measurements for the corrosion of C-steel in $1.0 \mathrm{~mol} \cdot \mathrm{L}^{-1} \mathrm{H}_{2} \mathrm{SO}_{4}$ without and with $250 \mathrm{mg} \cdot \mathrm{L}^{-1}$ of methanolic Bauhinia purpurea extract for different immersion times $(24,48$ and $72 \mathrm{~h}$ ) are provided in Table 4. These tests demonstrated the stability of the extract versus time variation. The $\mathrm{C}$-steel corrosion rate was reduced with the addition of the extract for all immersion times. It is noted a slight decrease in $\eta \%$ with time, from

Table 2: Electrochemical parameters obtained from EIS plots for C-steel in $1.0 \mathrm{~mol} \mathrm{~L}^{-1} \mathrm{H}_{2} \mathrm{SO}_{4}$ with and without methanolic Bauhinia purpurea leaf extract at the following concentrations: $50,125,250$ and $500 \mathrm{mg} \cdot \mathrm{L}^{-1}$.

\begin{tabular}{|c|c|c|c|c|c|}
\hline Inhibitor $\left(\mathrm{mg} \cdot \mathrm{L}^{-1}\right)$ & $\boldsymbol{R}_{c t}\left(\mathrm{Ohm} \cdot \mathrm{cm}^{2}\right)$ & $\alpha$ & $Q\left(\mu \mathrm{Mho} \cdot \mathrm{cm}^{-2}\right)$ & $f_{\max }(\mathrm{Hz})$ & $\eta(\%)$ \\
\hline 0 & 27.292 & 0.898 & 750 & 12.4 & - \\
\hline 50 & 37.317 & 0.901 & 592 & 9.9 & 26.8 \\
\hline 125 & 35.687 & 0.906 & 545 & 12.4 & 23.5 \\
\hline 250 & 42.110 & 0.889 & 451 & 9.9 & 35.1 \\
\hline 500 & 53.043 & 0.887 & 308 & 15.8 & 48.5 \\
\hline
\end{tabular}
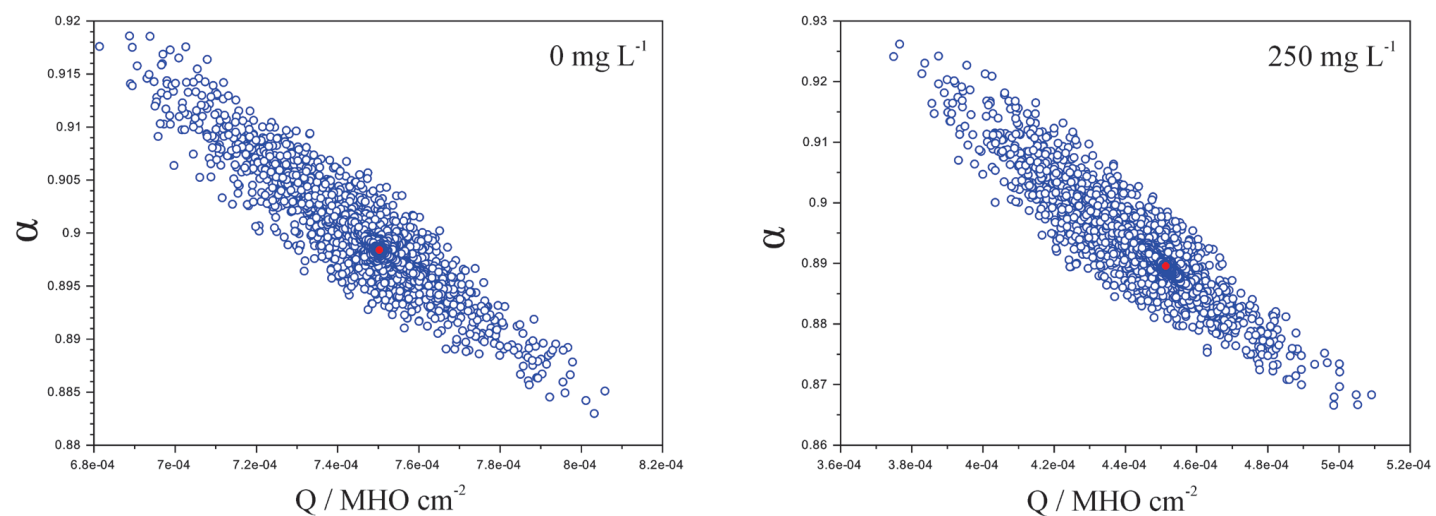

Figure 5: The 99\% confidence region of $\mathrm{Q}$ and $\alpha$ obtained by differential evolution fit for EIS data of C-steal in $1.0 \mathrm{~mol} \cdot \mathrm{L}^{-1} \mathrm{H}_{2} \mathrm{SO}_{4}$ in absence and presence of $250 \mathrm{mg} \cdot \mathrm{L}^{-1}$ of methanolic Bauhinia purpurea extract. 
Table 3: C-steel weight loss data in $1.0 \mathrm{~mol} \mathrm{~L}^{-1} \mathrm{H}_{2} \mathrm{SO}_{4}$ with and without methanolic Bauhinia purpurea leaf extract at the following concentrations: $50,125,250$ and $500 \mathrm{mg} \mathrm{L}^{-1}$.

\begin{tabular}{ccc}
\hline Inhibitor $\left(\mathbf{m g} \cdot \mathbf{L}^{-1}\right)$ & $\left.\boldsymbol{W}_{\text {corr }} \mathbf{( m g} \cdot \mathbf{c m}^{-\mathbf{2}} \cdot \mathbf{h}^{-\mathbf{1}}\right)$ & $\boldsymbol{\eta} \mathbf{( \% )}$ \\
\hline 0 & $2.13 \pm 0.04$ & - \\
50 & $0.89 \pm 0.09$ & $58 \pm 4$ \\
125 & $0.55 \pm 0.01$ & $74 \pm 1$ \\
250 & $0.57 \pm 0.01$ & $73 \pm 1$ \\
500 & $0.43 \pm 0.02$ & $80 \pm 1$ \\
\hline
\end{tabular}

Table 4: C-steel weight loss data in $1.0 \mathrm{~mol} \mathrm{~L}^{-1} \mathrm{H}_{2} \mathrm{SO}_{4}$ without and with $250 \mathrm{mg} \mathrm{L}^{-1}$ of methanolic Bauhinia purpurea extract at the following immersion times: 24,48 and $72 \mathrm{~h}$ at $25^{\circ} \mathrm{C}$.

\begin{tabular}{|c|c|c|c|}
\hline \multirow{2}{*}{$\begin{array}{c}\text { Immersion } \\
\text { time (h) }\end{array}$} & \multicolumn{2}{|c|}{$W_{\text {corr }}\left(\mathbf{m g} \cdot \mathbf{c m}^{-2} \cdot \mathbf{h}^{-1}\right)$} & \multirow{2}{*}{$\eta(\%)$} \\
\hline & Without & With & \\
\hline 24 & $2.13 \pm 0.04$ & $0.57 \pm 0.01$ & $73 \pm 1$ \\
\hline 48 & $1.98 \pm 0.04$ & $0.57 \pm 0.02$ & $71 \pm 1$ \\
\hline 72 & $2.01 \pm 0.02$ & $0.64 \pm 0.01$ & $68 \pm 1$ \\
\hline
\end{tabular}

$73 \%$ to $68 \%$ after $24 \mathrm{~h}$ and $72 \mathrm{~h}$ of immersion, respectively, indicating that the inhibition efficiency remains after long periods of immersion.

The effects of temperature on the corrosion of C-steel in $1.0 \mathrm{~mol} \cdot \mathrm{L}^{-1} \mathrm{H}_{2} \mathrm{SO}_{4}$ with or without $250 \mathrm{mg} \cdot \mathrm{L}^{-1}$ of methanolic Bauhinia purpurea extract ranging from 25 to $55^{\circ} \mathrm{C}$ after $2.0 \mathrm{~h}$ of immersion time are presented in Table 5. The corrosion rates of the steel in both free and inhibited acid media increased with the temperature. The inhibition efficiency of the methanolic Bauhinia purpurea extract remained almost constant with temperature change, slightly decreasing with temperature increase.

Clearly, the weight loss is always superior in blank condition than with $250 \mathrm{mg} \cdot \mathrm{L}^{-1}$ in the temperature range of $25-55^{\circ} \mathrm{C}$, as depicted in Figure 6. Moreover, the apparent activation energy for $\mathrm{C}$-steel corrosion in both $\mathrm{H}_{2} \mathrm{SO}_{4}$ solution and in inhibiting acid solution was determined from an Arrhenius-type plot according to Equation 5:

$\log W_{\text {corr }}=\frac{-E_{a}}{2.303 R T}+\log A$

where $W_{\text {corr }}$ is the corrosion rate, $E_{a}$ is the apparent activation energy, $A$ is the pre-exponential factor, $T$ is the absolute temperature and $R$ is the molar gas constant. Arrhenius plots of $\left(\log W_{\text {corr }}\right)$ against $(1 / T)$ for C-steel in $1.0 \mathrm{~mol} \cdot \mathrm{L}^{-1} \mathrm{H}_{2} \mathrm{SO}_{4}$ both in the absence and presence of the methanolic Bauhinia purpurea extract are shown in Figure 6.

The apparent activation energy obtained for the corrosion process in the free acid solution was found to be $51.2 \mathrm{~kJ} \cdot \mathrm{mol}^{-1}$ and $65.8 \mathrm{~kJ} \cdot \mathrm{mol}^{-1}$ in the presence of the inhibitor. The energy barrier of the corrosion reaction increased in the presence of inhibitor and the inhibition efficiency slightly decreased with temperature (Table 5). Such observations could be explained by a physical adsorption of the inhibitor onto the metal/solution interface ${ }^{28}$.

Physical adsorption is a result of electrostatic attraction between charged metal surface and charged species in the nearby solution. Adsorption of negatively charged species is
Table 5: C-steel weight loss data in $1.0 \mathrm{~mol} \mathrm{~L}-1 \mathrm{H} 2 \mathrm{SO} 4$ without and with $250 \mathrm{mg} \mathrm{L}-1$ of methanolic Bauhinia purpurea extract at the following immersion temperatures: $25,35,45$ and $55 \mathrm{oC}$ with an immersion period of 2.0 hours.

\begin{tabular}{|c|c|c|c|}
\hline \multirow{2}{*}{$\begin{array}{c}\text { Temperature } \\
\left({ }^{\circ} \mathrm{C}\right)\end{array}$} & \multicolumn{2}{|c|}{$W_{\text {corr }}\left(\mathrm{mg} \cdot \mathrm{cm}^{-2} \cdot \mathbf{h}^{-1}\right)$} & \multirow{2}{*}{$\eta(\%)$} \\
\hline & Without & With & \\
\hline 25 & $1.62 \pm 0.26$ & $0.67 \pm 0.02$ & $59 \pm 9$ \\
\hline 35 & $3.56 \pm 0.08$ & $1.45 \pm 0.07$ & $59 \pm 2$ \\
\hline 45 & $6.78 \pm 0.07$ & $2.90 \pm 0.06$ & $57 \pm 1$ \\
\hline 55 & $12.11 \pm 0.13$ & $7.08 \pm 0.07$ & $42 \pm 1$ \\
\hline
\end{tabular}

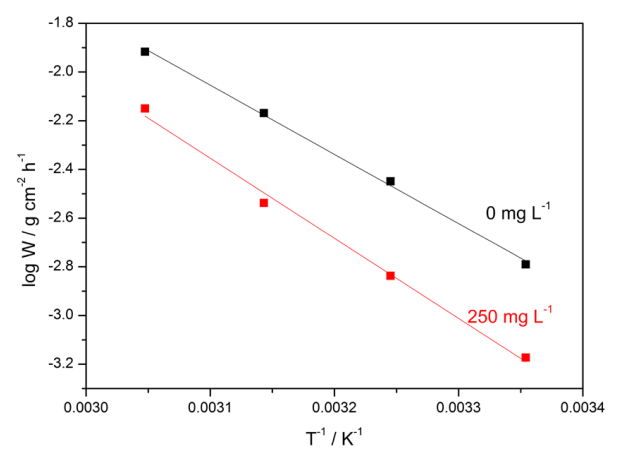

Figure 6: Arrhenius plot for the $\mathrm{C}$-steel corrosion rate in $1.0 \mathrm{~mol} \cdot \mathrm{L}^{-1} \mathrm{H}_{2} \mathrm{SO}_{4}$ in absence and presence of $250 \mathrm{mg} \cdot \mathrm{L}^{-1}$ of methanolic Bauhinia purpurea extract.

facilitated if the metal surface is positively charged. Positively charged species can also protect the positively charged metal surface acting with a negatively charge intermediate, such as acid anions adsorbed on the metal surface. In addition, components of the methanolic Bauhinia purpurea extract can also be present as protonated species (positive charge) in an acid solution adsorbing onto metal surface ${ }^{29}$.

\subsection{Surface morphology}

Figure 7 shows a SEM micrograph of C-steel immersed for $2.0 \mathrm{~h}$ in $1.0 \mathrm{~mol} \cdot \mathrm{L}^{-1} \mathrm{H}_{2} \mathrm{SO}_{4}$ in the absence (Fig. 7A) and presence of $250 \mathrm{mg} \cdot \mathrm{L}^{-1}$ of methanolic Bauhinia purpurea extract (Fig. 7B) at $25^{\circ} \mathrm{C}$. The morphology in Fig. 7A shows a rough surface, a characteristic of the uniform corrosion of $\mathrm{C}$-steel in acid. In the presence of the inhibitor (Fig. 7B), a smooth surface can be observed, indicating that the surface was covered by an inhibitor.

\subsection{Adsorption isotherm}

The change of $\theta$ with extract concentration specifies the adsorption isotherm that describes the system (Figure 8). The fitting of the obtained data to the Langmuir isotherm is illustrated by plotting according to equation (6). In this equation, $C$ is the concentration, $\theta$ the occupied fraction of surface and $K$ the adsorption constant. The adjust of the Langmuir adsorption isotherm was very good, with $r^{2}$ close to 0.998 . This behavior suggests that compounds present in the methanolic Bauhinia purpurea extracts were adsorbed onto the $\mathrm{C}$-steel surface according to a Langmuir adsorption 


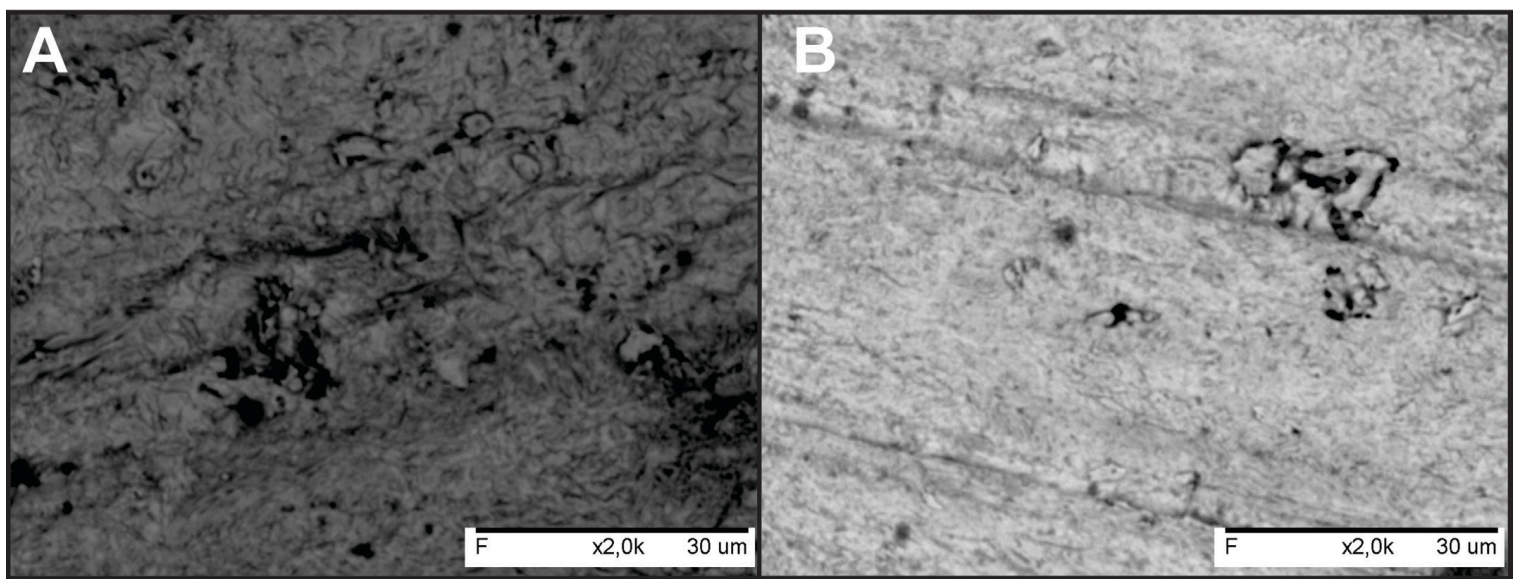

Figure 7: SEM micrograph (2000x) of C-steel immersed in $1.0 \mathrm{~mol} \cdot \mathrm{L}^{-1} \mathrm{H}_{2} \mathrm{SO}_{4}$ in the absence (A) and presence of $250 \mathrm{mg} \cdot \mathrm{L}^{-1}$ of methanolic Bauhinia purpurea extract (B).

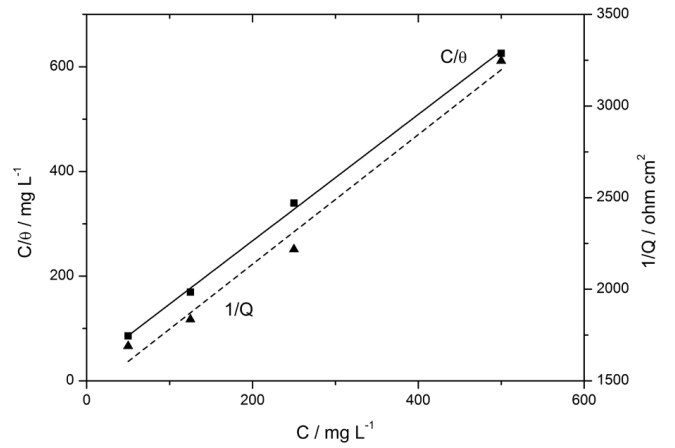

Figure 8: Langmuir adsorption isotherm of of methanolic Bauhinia purpurea extract on the C-steel surface in $1.0 \mathrm{~mol} \cdot \mathrm{L}^{-1} \mathrm{H}_{2} \mathrm{SO}_{4}$, and 1/Q relation with methanolic Bauhinia purpurea extract concentration.

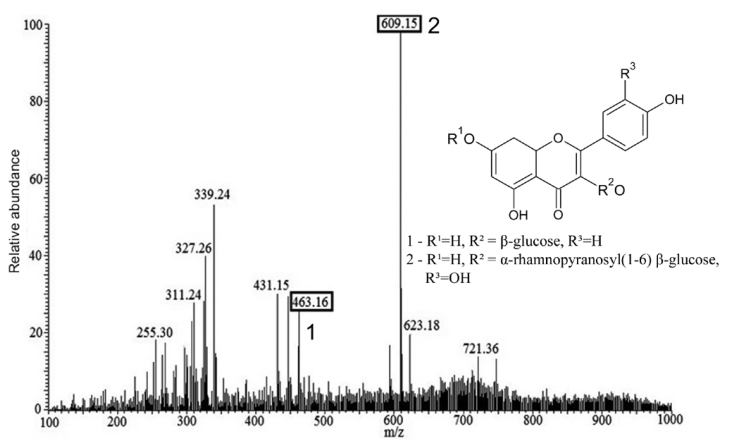

Figure 9: MS-ESI of methanolic Bauhinia purpurea extracts and chemical structure of isoquercetrin (1) and rutin (2).

isotherm, indicating the absence of interaction forces amongst adsorbed molecules.

$\frac{C}{\theta}=C+\frac{1}{K}$

As Langmuir isotherm is valid for the present results, the increase of concentration also increases the surface coverage.

The CPE parameter $(\mathrm{Q})$ adjusted in the equivalent circuit is proportional to the active area $^{22}$. Therefore the active metallic surface reduces and the $\mathrm{Q}$ parameter decreases proportionally as shown in Figure 8.

The production of the extracts by a methanolic route preserves the flavonoids present in the plant ${ }^{30}$, as shown in Figure 9. The mass spectra of the methanolic Bauhinia purpurea extract shows the presence of rutin $(609 \mathrm{~m} / \mathrm{z})$ and isoquercetrin $(463 \mathrm{~m} / \mathrm{z})$. The observed ions indicate the presence of other flavonoids (i.e. $\mathrm{m} / \mathrm{z} 477$ ) compatible with isorhamnetin derivatives. Phenolic compounds have known effects as corrosion inhibitors of carbon stee ${ }^{31,32}$ and zinc in $\mathrm{NaCl}^{33}$. For instance, the flavonoid 3-hydroxy-7-methoxy-2phenylchromen-4-one identified by Ezhilarasi et al. ${ }^{34}$ follows the Langmuir adsorption isotherm and showed mixed type corrosion inhibition, which is a similar result to the one found in the present paper for the methanolic Bauhinia purpurea leaf extract. The more specific compound, rutin ${ }^{35}$, also detected in the extract of the present paper, exhibited a protective effect in $\mathrm{HCl}$ medium. Therefore, the flavonoids from diverse origins are potential corrosion inhibitors, including the ones presented in the Bauhinia purpurea leaf extract.

\section{Conclusions}

The Bauhinia purpurea (Fabaceae) extract shows a reasonable efficiency on carbon steel in sulfuric acid medium $\left(1.0 \mathrm{~mol} \cdot \mathrm{L}^{-1} \mathrm{H}_{2} \mathrm{SO}_{4}\right.$ ) at $25^{\circ} \mathrm{C}$. Moreover:

1. The results found in polarization measurement show that these inhibitors adsorb on carbon steel surface. A concentration-dependent reduction of both the anodic and cathodic current densities was observed together with a shift of the corrosion potential to the noble direction, thus suggesting an inhibition of the metal dissolution process and hydrogen evolution by the surface blocking effect.

2. The adsorption process followed a Langmuir adsorption isotherm.

3. The Arrhenius plot indicated a physisorption process, with an activation energy of $65.8 \mathrm{~kJ} \cdot \mathrm{mol}^{-1}$ in the presence of $250 \mathrm{mg} \cdot \mathrm{L}^{-1}$ of extract. 
4. The inhibitory efficiency of the extract remained stable up to 72 hours at room temperature.

5. The active species of the Bauhinia purpurea extract are probably the flavonoids that were detected by mass spectrometry.

6. The Q parameters of constant phase element decreases linearly with the Bauhinia purpurea extract concentration.

\section{References}

1. Gece G. Drugs: A review of promising novel corrosion inhibitors. Corrosion Science. 2011; 53(12):3873-3898. http://dx.doi. org/10.1016/j.corsci.2011.08.006.

2. Mobin M and Masroor S. Alkanediyl- $\alpha, \omega$-bis (Dimethyl Cetylammoniaum Bromide) gemini surfactants as novel corrosion Inhibitors for mild steel in formic acid. Materials Research. 2012; 15(6):837-847. http://dx.doi.org/10.1590/ S1516-1439201200500011.

3. Pereira SS, Pêgas MM, Fernández TL, Magalhães M, Schöntog TG, Lago DC, et al. Inhibitory action of aqueous garlic peel extract on the corrosion of carbon steel in $\mathrm{HCl}$ solution. Corrosion Science. 2012; 65:360-366. http://dx.doi.org/10.1016/j. corsci.2012.08.038.

4. Rani BE and Basu, BB. Green inhibitors for corrosion protection of metals and alloys: An overview. International Journal of Corrosion. 2012; (2012):1-15. http://dx.doi. org/10.1155/2012/380217.

5. Roberge PR. Corrosion inhibitors. In: Roberge PR. Handbook of corrosion engineering. New York: McGraw-Hill; 1999.

6. Boonphong S, Puangsombat P, Baramee A, Mahidol C, Ruchirawat $\mathrm{S}$ and Kittakoop P. Bioactive compounds from Bauhinia purpurea possessing antimalarial, antimycobacterial, antifungal, anti-inflammatory, and cytotoxic activities. Journal of Natural Products. 2007; 70(5):795-801. http://dx.doi. org/0.1021/np070010e.

7. Santos PM, Almeida PD, Lima ES, Moraes MO, Costa PM and Meira AS. Ó Pessoa C, Valente LM, Veiga Junior, VF. Perfil de flavonoides e avaliação do potencial antioxidante e citotóxico de Bauhinia purpurea (Fabaceae) da região amazônica. Quimica Nova. 2014; 37(1):89-94. http://dx.doi.org/10.1590/ S0100-40422014000100017.

8. Muralikrishna KS, Latha KP, Shreedhara CS, Vaidya VP and Krupanidhi AM. Effect of Bauhinia purpurea Linn. of Alloxaninduced diabetic rats and isolated frog's heart. International Journal of Green Pharmacy. 2008; 2(2):83-86. http://dx.doi. org/10.4103/0973-8258.41176.

9. Panda S and Kar A. Withania sonnifera and Bauhinia purpurea in the regulation of circulating thyroid hormone concentrations in female mice. Journal of Ethnopharmacology. 1999; 67(2):233239. http://dx.doi.org/10.1016/S0378-8741(99)00018-5.

10. Pettit GR, Numata A, Iwamoto C, Usami Y, Yamada T, Ohishi $\mathrm{H}$, et al. Antineoplastic agents. 551 - Isolation and structure of bauhiniastatins 1 - 4 from Bauhinia purpurea. Journal of Natural Products. 2006; 69(3):323-327. http://dx.doi.org/10.1021/ np058075+.

11. Shreedhara CS, Vaidya VP, Vagdevi HM, Latha KP, Muralikrishna KS and Krupanidhi AM. Screening of Bauhinia purpurea Linn. for analgesic and anti-inflammatory activities. Indian Journal of Pharmacology. 2009; 41(2):75-79. http://dx.doi. org/10.4103\%2F0253-7613.51345.
7. The correlation between $\mathrm{Q}$ parameter and $\alpha$ dispersion model present a quasi linear behavior.

\section{Acknowledgements}

The authors acknowledge the financial support of the Brazilian Agencies FAPERJ, CAPES and CNPq.

12. Zakaria ZA. Free radical scavenging activity of some plants available in Malaysia. Iranian Journal of Pharmacology Therapeutics. 2007; 6(2):87-91.

13. Zakaria ZA, Wen LY, Rahman NI, Ayub AH, Sulaiman MR and Gopalan HK. Antinociceptive, anti-inflammatory and antipyretic properties of the aqueous extract of Bauhinia purpurea leaves in experimental animals. Medical Principles and Practice. 2007; 16(6):443-449. http://dx.doi.org/10.1159/000107749.

14. Zakaria ZA, Rofiee MS, Teh LK, Salleh MZ, Sulaiman MR and Somchit MN. Bauhinia purpurea leaves extracts exhibited in vitro antiproliferative and antioxidant activities. African Journal of Biotechnology. 2011; 10(1):65-74. http://dx.doi. org/10.5897/AJB10.1354.

15. Yadav RN and Tripathi P. A novel flavone glycoside from the stem of Bauhinia purpurea. Fitoterapia. 2000; 71(1):88-90. http://dx.doi.org/10.1016/S0367-326X(99)00114-8.

16. Salatino A, Blatt CT, Santos DY and Vaz AM. Foliar flavonoids of nine species of Bauhinia. Brazilian Journal of Botany. 1999; 22(1):17-20. http://dx.doi.org/10.1590/S0100-84041999000100003.

17. Ramadan MF, Sharanabasappa G, Seetharam YN, Seshagiri $\mathrm{M}$ and Moeersel JT. Characterization of fatty acids and bioactive compounds of kachnar (Bauhinia purpurea L.). Food Chemistry. 2006; 98(2):359-365. http://dx.doi.org/10.1016/j. foodchem.2005.06.018.

18. Keinänen M. Comparison of methods for the extraction of flavonoids from birch leaves (Betula pendula Roth.) carried out using high-performance liquid chromatography. Journal of Agricultural and Food Chemistry. 1993; 41(11):1986-1990. http://dx.doi.org/10.1021/jf00035a032.

19. Aboshora W, Lianfu Z, Dahir M, Qingran M, Qingrui S, Jing L, et al. Effect of extraction method and solvent power on polyphenol and flavonoid levels in Hyphaene thebaica L mart (Arecaceae) (Doum) fruit, and its antioxidant and antibacterial activities. Tropical Journal of Pharmaceutical Research. 2014; 13(12):2057-2063. http://dx.doi.org/10.4314/tjpr.v13i12.16.

20. Storn R and Price K. Differential evolution - A simple and efficient heuristic for global optimization over continuous spaces. Journal of Global Optimization. 1997; 11(4):341-359. http://dx.doi.org/10.1023/A:1008202821328.

21. Li X, Deng S and Fu H. Blue tetrazolium as a novel corrosion inhibitor for cold rolled steel in sulfuric acid solution. Materials Chemistry and Physics. 2011; 129(3):696-700. http://dx.doi. org/10.1016/j.matchemphys.2011.05.042.

22. Orazem ME and Tribollet B. Electrochemical impedance spectroscopy. New Jersey: John Wiley \& Sons; 2008.

23. Córdoba-Torres P, Mesquita TJ and Nogueira RP. Influence of geometry-induced current and potential distributions on the characterization of constant-phase element-phase behaviour. Electrochimica Acta. 2013; 87(1):676-685. http://dx.doi. org/10.1016/j.electacta.2012.09.060.

24. Kerner $Z$ and Pajkossy T. Impedance of rough capacitive electrodes: the role of surface disorder. Journal of Electroanalytical Chemistry. 1998; 448(1):139-142. http://dx.doi.org/10.1016/ S0022-0728(98)00025-4. 
25. Rammelt U and Reinhard G. On the applicability of a constant phase element (CPE) to the estimation of roughness of solid metal electrodes. Electrochimica Acta. 1990; 35(6):1045-1049. http://dx.doi.org/10.1016/0013-4686(90)90040-7.

26. Schwaab M, Biscaia Jr EC, Monteiro JL and Pinto JC. Nonlinear parameter estimation through particle swarm optimization. Chemical Engineering Science. 2008; 63(6):1542-1552. http:// dx.doi.org/10.1016/j.ces.2007.11.024.

27. Patel NS, Jauhari S and Mehta GN. Mild steel corrosion inhibition by Bauhinia purpurea leaves extract in $1 \mathrm{~N}$ sulphuric acid. Arabian Journal for Science and Engineering. 2009; 34(2C):61-69.

28. Satapathy AK, Gunasekaran G, Sahoo SC, Amit K and Rodrigues PV. Corrosion inhibition by Justicia gendarussa plant extract in hydrochloric acid solution. Corrosion Science. 2009; 51(12):28452856. http://dx.doi.org/10.1016/j.corsci.2009.08.016.

29. Dehri I and Özcan M. The effect of temperature on the corrosion of mild steel in acidic media in the presence of some sulphurcontaining organic compounds. Materials Chemistry and Physics. 2006; 98(2-3):316-323. http://dx.doi.org/10.1016/j. matchemphys.2005.09.020.

30. Stalikas CD. Extraction, separation, and detection methods for phenolic acids and flavonoids. Journal of Separation Science. 2007; 30(18):3268-3298. http://dx.doi.org/10.1002/ jssc. 200700261
31. Nofrizal S, Rahim AA, Saad B, Raja PB, Shah AM and Yahya $\mathrm{S}$. Elucidation of the corrosion inhibition of mild steel in 1.0 $\mathrm{M} \mathrm{HCl}$ by catechin monomers from commercial green tea extracts. Metallurgical and Materials Transactions. A, Physical Metallurgy and Materials Science. 2012; 43A(4):1382-1393. http://dx.doi.org/10.1007/s11661-011-1030-3.

32. Tan KW and Kassim MJ. A correlation study in the phenolic profiles and corrosion inhibition properties of mangrove tannins (Rhizophora apiculata) as affected by extraction solvents. Corrosion Science. 2011; 53(2):569-574. http://dx.doi. org/10.1016/j.corsci.2010.09.065.

33. Suedile F, Robert F, Roos C and Lebrini M. Corrosion inhibition of zinc by Mansoa alliacea plant extract in sodium chloride media: extraction, characterization and electrochemical studies. Electrochimica Acta. 2014; 133(1):631-638. http://dx.doi. org/10.1016/j.electacta.2013.12.070

34. Ezhilarasi JC and Nagarajan P. Corrosion inhibition and adsorption properties of a flavonoid compound for mild steel in acidic medium. Journal of the Korean Chemical Society. 2011; 55(3):495-501. http://dx.doi.org/10.5012/jkcs.2011.55.3.495.

35. Nagarajan P, Princy JM, Ezhilarasi JC, Kavitha D and Sulochana N. Natural product extract as eco-friendly corrosion inhibitor for commercial mild steel in 1M HCI-Part II. Journal of Indian Council of Chemists. 2009; 26(2):53-157. 